DR JULIEN CHARREAU (Orcid ID : 0000-0001-9313-0450)

DR AMANDINE SARTÉGOU (Orcid ID : 0000-0002-3436-6946)

Article type : Paper

\title{
Late Miocene to Quaternary slip history across the Qiulitag anticline in the southern Tianshan piedmont
}

Julien Charreau ${ }^{l, *}$, Amandine Sartégou ${ }^{l}$, Dimitri Saint-Carlierl, Jérôme Lavél, Pierre-Henri Blard ${ }^{l}$, Stéphane Dominguez ${ }^{2}$, Sheng Li Wang ${ }^{3}$, Gang Rao ${ }^{4}$ and ASTER Team ${ }^{5,+}$

1. CRPG, CNRS, Université de Lorraine, UMR 7358, 54501 Vandœuvre-lès-Nancy, France, julien.charreau@univlorraine.fr, dimitrisaint@gmail.com, amandine.sartegou@gmail.com, jerome.lave@univ-lorraine.fr, pierrehenri.blard@univ-lorraine.fr

2. Laboratoire Géosciences Montpellier, Université de Montpellier; UMR CNRS/UMII 5243, 34095 Montpellier Cedex, France,dominguez@gm.univ-montp2.fr

3. School of Earth Sciences and Engineering, Nanjing University, 163 Xianlin Ave, Qixia District, Nanjing Jiangsu Province, 210046,wangsl@nju.edu.cn

4. School of Earth Sciences, Zhejiang University, Hangzhou 310027, China, raogang@zju.edu.cn

5. Aix-Marseille Université, CNRS-IRD-Collège de France, UM 34 CEREGE, Technopôle de l'Environnement Arbois-Méditerranée, BP80, 13545 Aix-en-Provence, France

* corresponding author: julien.charreau@univ-lorraine.fr

+ Georges Aumaître, Didier L. Bourlès, Karim Keddadouche

To be submitted to Terra Nova

\section{ABSTRACT}

In this study, we reconstruct the Miocene to Quaternary shortening history across the Qiultag anticline, a complex fault-bend fold located in southern Tianshan. We studied the Yaha and Kuche

This article has been accepted for publication and undergone full peer review but has not been through the copyediting, typesetting, pagination and proofreading process, which may lead to differences between this version and the Version of Record. Please cite this article as doi: 10.1111/TER.12439

This article is protected by copyright. All rights reserved 
sections, where we combined surface structural measurements and seismic imaging to model the stratigraphic horizons. The history of folding was reconstructed based on magnetostratigraphic analyses and eight cosmogenic burial ages in Kuche. Pleistocene deformation rates were also quantified in Yaha based on a deformed fluvial terrace that we dated to $\sim 67 \mathrm{ka}$ using a cosmogenic depth profile. Our results suggest that the fold grew at a mean slip rate of $0.9-1.3 \mathrm{~mm} / \mathrm{a}$ in both sections but accelerated to $\sim 2.5 \mathrm{~mm} / \mathrm{a}$ during the Pleistocene in Kuche. These results support a migration of the deformation toward the basin during the Pleistocene and suggest that most of the present deformation of the Tianshan is accommodated across the external structures of the range.

\section{INTRODUCTION}

The Tianshan range is one of the most active intracontinental orogenic belts (e.g. Reigber et al., 2001). Its geological history (e.g. Dumitru et al., 2001; Windley et al., 1990), which included a Cenozoic reactivation of inherited structures in response to the India-Asia collision, has resulted in a complex present day topography. Documenting how crustal shortening is accommodated within these reliefs is a critical step toward gaining a better understanding of how the Tianshan range is growing and how total deformation due to the collision with India is distributed across the Asian continent. This is particularly true along the two piedmonts of the Tianshan, which accommodate most of the deformation across the range (Charreau et al., 2017; Thompson et al., 2002) and for which more quantitative studies along individual faults are still needed. Here, we focus our analyses on the Qiulitag anticline in the piedmont of the southern eastern Tianshan, and analyze the Kuche and Yaha sections, where the geometry and structures of the fold have been documented from remarkable outcrops and two seismic profiles (Fig. 1) (Hubert-Ferrari et al., 2007; Sun et al., 2009) and whose depositional ages have already been constrained from magnetostratigraphic analyses (Charreau et al., 2009, 2006; Sun et al., 2009).

\section{THE QIULITAG ANTICLINE}

The Qiulitag anticline is a $225 \mathrm{~km}$ long fault-bend fold, 5-7 km in width and presenting up to $\sim 1000 \mathrm{~m}$ of relief (Hubert-Ferrari et al., 2007). The two seismic lines conducted across the Kuche and Yaha sections reveal a relatively similar structure, composed of two distinct structural levels, in both sections (e.g. Hubert-Ferrari et al., 2007; Sun et al., 2009). A first anticline with low-angle limbs lies on an $8-10 \mathrm{~km}$ deep thrust ramp. This anticline is overlain by a second wedging system 
that developed on shallower decollement levels $(5-6 \mathrm{~km})$ producing the anticline seen at the surface (e.g. Hubert-Ferrari et al., 2007) (Fig 1). In both sections, the Yakeng anticline, located in the southern part of Qiulitag, is linked at depth to this upper wedging structure by a common detachment (Figs. 1b, c and d).

In Kuche, two faults belonging to this upper system have broken through the surface in the core of the anticline, steepening the strata up to the vertical and even slightly overturning the fold to the north. In Yaha, the fold exhibits a box shape at the surface that developed on a low angle northward thrust ramp breaking through the southern limb of the fold (Figs. 1 and 2). Several wellpreserved flat surfaces of one fluvial terrace can be traced relatively continuously over $\sim 1.5 \mathrm{~km}$ across the southern limb of the Qiulitag fold (Fig. 2).

In Kuche, we focus our analyses on the southern limb of the fold (Fig. 1) where a 3780-m-thick magnetostratigraphic section has provided depositional ages of $\sim 13 \mathrm{Ma}$ up to $\sim 3 \mathrm{Ma}$ (Fig. 2) (Sun et al., 2009). Above this section, the sediments are mainly composed of the coarse Xiyu conglomerates (Fig. 2) (e.g. Charreau et al., 2009) and remain poorly dated. In Yaha, the depositional ages of the sediments have also been constrained by magnetostratigraphy but here, in the northern limb of the fold, the ages range from $\sim 13 \mathrm{Ma}$ to $1.5 \mathrm{Ma}$ (Fig. 1d) (Charreau et al., 2009, 2006).

\section{METHODS}

\section{Cosmogenic dating}

To better constrain the depositional ages of the sediments in the upper conglomeratic part of the Kuche section, we use ${ }^{26} \mathrm{Al} /{ }^{10} \mathrm{Be}$ cosmogenic burial dating (e.g. Granger and Muzikar, 2001). We collected eight samples of quartzite cobbles and pebbles along the Kuche river, at well-shielded sites to minimize their recent exposure to cosmic rays (Fig. 2). We processed and analyzed together 20 to 30 individual cobbles and pebbles per sampling site. Moreover, to estimate the initial ${ }^{26} \mathrm{Al} /{ }^{10} \mathrm{Be}$ ratio potentially inherited from a previous cycle of erosion/deposition, we also analysed one sample of sand collected in the present riverbed upstream of the section studied.

The abandonment age of the alluvial surface left in the Yaha section was inferred from a 4-mdepth cosmogenic profile (e.g. Gosse and Phillips, 2001) composed of 5 samples of sand at depth and three cobbles collected on the surface (Fig. 2).

Burial ages were calculated from the measured ${ }^{10} \mathrm{Be}$ and ${ }^{26} \mathrm{Al}$ concentrations and the mean elevation of the present drainage basin using the Matlab® ${ }^{\circledR}$ code of Blard et al. (Blard et al., 2019). 
To derive exposure ages from the depth profile, we followed a Monte Carlo inversion procedure that tests thousands of parameter combinations to find the best fitting solution by minimizing the difference between the model and the data (Fig. $\left.\mathrm{F}^{1}\right)($ Saint-Carlier et al., 2016).

More details are given in the supplementary information.

\section{Slip rates}

We documented the long-term (1-13 Ma) slip history recorded across the fold by modeling the stratigraphic horizons (Fig. $\mathrm{A}^{1}$ ). Based on the depth geometry of the fold, constrained by seismic imaging (Fig. $\mathrm{B}^{1}$ and Hubert-Ferrari et al., 2007), we predicted the evolution of bedding at the surface assuming only pre-growth strata layers. Any discrepancy between the predicted values and the dip measured at the surface may reveal the presence of syn-tectonic growth strata (Fig. 3) (Charreau et al., 2008). This technique, provides only a minimum age for the fold initiation as older syntectonic layers may not have been taken into account due to erosion (Figs. $\mathrm{C}^{1}$ and $\mathrm{D}^{1}$ ). Using a simple geometric formulation of the displacement assuming growth by a curved hinge kink-band migration (Suppe et al., 1997), the geometry of any syntectonic layer deposited across the axial surfaces during folding can then be modeled and fitted to the observed dip at the surface (Charreau et al., 2008). In both sections, we modeled a set of 5-10 syntectonic horizons (Figs. 3 and 4) and constrained their ages based on their horizontal positions along the present river with respect to the magnetostratigraphic correlations (Charreau et al., 2009, 2006; Sun et al., 2009) or, in the upper part of the Kuche section, by extrapolating the mean sediment accumulation rates derived from our burial ages.

In Yaha, we also quantified the amount of the recent $(<1 \mathrm{Ma})$ slip accommodated in the southern limb by measuring the deformation recorded by the abandoned fluvial terrace (Figs. 2 and $\mathrm{D}^{1}$ ).

\section{RESULTS}

\section{Cosmogenic dating}

The concentrations of ${ }^{10} \mathrm{Be}$ and ${ }^{26} \mathrm{Al}$ measured in the burial-age samples (Table 1a) yield ${ }^{26} \mathrm{Al} /{ }^{10} \mathrm{Be}$ ratios ranging from $0.5 \pm 0.5$ to $2.9 \pm 1.7$, from which we derive burial ages of $5.4 \pm 2.0$ Ma to $1.9 \pm 1.1$ Ma assuming an initial ratio of 6.5 (Table $1 \mathrm{a}$ and $\mathrm{Fig}$. $\mathrm{F}^{1}$ ). If we take the ${ }^{26} \mathrm{Al} /{ }^{10} \mathrm{Be}$ ratio of $3.7 \pm 0.5$ measured in the present river bed sediments to be the initial ratio and assume it to be representative of the inheritance for the whole section, then the corrected burial ages obtained range from $4.1 \pm 2.3 \mathrm{Ma}$ to $0.6 \pm 1.4 \mathrm{Ma}$ (Table 1a). Despite large uncertainties, the corrected 
cosmogenic burial ages are relatively consistent with the magnetostratigraphic correlation of Sun et al. (2009) (Fig. 2). Though the mean ages obtained for KU3 and KU7 are older than the underlying samples, they remain consistent with their ages if we consider their large uncertainties. Together with the magnetostratigraphic data from the top of the Sun section (Sun et al., 2009), these new burial ages constrain the sediment accumulation rates to $315 \pm 10 \mathrm{~m} / \mathrm{Ma}$. Table $1 \mathrm{~b}$ details the cosmogenic results obtained for samples collected across the depth profile studied in the Yaha section. This profile exhibits the classic exponential decrease in ${ }^{10} \mathrm{Be}$ concentration and its inversion constrains the abandonment age of the terrace to $68.3+4.9 /-10.3 \mathrm{ka}$ (Fig. $2 \mathrm{~b}$ and $\mathrm{G}^{1}$ ).

\section{Slip history}

In Yaha, the strong change in bedding dip observed at $\sim 8 \mathrm{~km}$ is inconsistent with the expected angle if only pre-growth strata are considered (Fig. 3). The strata located north of this zone are therefore likely syntectonic, suggesting that the folding started by $\sim 5 \mathrm{Ma}$ at the latest. According to our modeling, the fold has accommodated at minimum a total slip of $\sim 4.8 \mathrm{~km}$ since $\sim 5 \mathrm{Ma}$, meaning that the fold grew at a mean slip rate of $\$ 1 \mathrm{~mm} / \mathrm{a}$. However, this bedding change occurs in less than $150 \mathrm{~m}$, which would be too rapid to correspond to the width of the hinge zone 1 (Fig. $3)$ even if syntectonic strata are considered. Regardless of the fold mechanism, this rapid change requires that the fold was initiated before $\sim 5$ Ma but must have grown relatively slowly $(<0.1$ $\mathrm{mm} / \mathrm{a}$ ?) at first in order to explain the relatively parallel strata within the hinge zone. According to our fold model, after $\sim 4 \mathrm{Ma}$ the fold grew at a higher mean slip rate of $1.3 \pm 0.2 \mathrm{~mm} / \mathrm{a}$. Since $\sim 2.3$ Ma in our model, a total of $\sim 1700 \mathrm{~m}$ of shortening has been accommodated across the fold, suggesting a lower slip rate of $\sim 0.7 \mathrm{~mm} / \mathrm{a}$ during the Quaternary. The vertical offset measured across the $67 \mathrm{kyr}$ old fluvial terrace is $15 \pm 3 \mathrm{~m}$ (Fig. 2) which corresponds to a slip (S) of $42 \pm 11 \mathrm{~m}$ and an associated lower slip rate of $0.6 \pm 0.2 \mathrm{~mm} / \mathrm{a}$. Similarly, the $52 \pm 3 \mathrm{~m}$ of offset measured above the northern most axial surface with respect to the present river bed would yield $56 \pm 2 \mathrm{~m}$ of slip $\left(\mathrm{S}^{\prime}\right)$ and a rate of $0.8 \pm 0.1 \mathrm{~mm} / \mathrm{a}$ (Figs. 2 and $\mathrm{D}^{1}$ ). This value must only be considered as a maximum because we neglect possible incision of the river in our calculation. These slip values derived from the deformed terraces in the southern limb of the fold can be added to the $0.7 \mathrm{~mm} / \mathrm{a}$ found across the northern limb to yield a total of 1.3-1.5 mm/a accommodated across the Qiulitag anticline in Yaha during the Pleistocene.

In Kuche, bedding dips measured at the surface continuously decrease from $\sim 80^{\circ}$ to $<5^{\circ}$ southwards while the expected angle for pre-growth strata should remain steady south of $10.5 \mathrm{~km}$ 
consistent with the monocline zone identified at depth (Fig. 4). This likely indicates the presence of syntectonic layers, meaning that the fold initiated at least $\sim 4$ Myr ago (Fig. 4). Assuming that all strata since that time are syntectonic, the fold grew continuously and relatively steadily until $\sim 0.8 \mathrm{Ma}$, at a mean slip rate of $0.9 \pm 0.2 \mathrm{~mm} / \mathrm{a}$. Since $\sim 0.8 \mathrm{Ma}$, a total of $\sim 1950 \mathrm{~m}$ of slip has been accommodated across the fold in our model, suggesting at first order a higher slip rate, which could be of $\sim 2.5 \mathrm{~mm} / \mathrm{a}$ during this period.

\section{DISCUSSION}

Our modeling relies on the assumptions that the fold grew by a curved hinge kink-band migration in both sections and that only the upper structures were recently active. According to HubertFerrari et al. (2007), the general morphology of the Qiulitag ridge is consistent with fault-bend folding and growth by kink-band migration and is mainly associated with the shallower anticline that we modeled. However, this morphology reflects only the recent history of folding and we cannot exclude earlier growth by limb rotation while the fold was being initiated on the detachment. Nevertheless, in assuming that, before the topographic emergence of the fold, the uplift balanced sedimentation, Hubert-Ferrari et al. (2007) also estimated a long-term slip rate of $\sim 0.6 \mathrm{~mm} / \mathrm{a}$. Based on the existence of giant triangular facets west of the Kuche section, these authors also proposed that the fold emerged very recently (220-280 ka, or later) and estimated a recent slip rate of 4-5 mm/a. Similarly, based on topographic measurements, Wu et al. (2006) estimated a slip rate of more than $3 \mathrm{~mm} / \mathrm{a}$ in the Kuche region. In the Yaha section, HubertFerrari et al. (2007), from a balanced cross section, estimated $\sim 5 \mathrm{~km}$ of horizontal shortening across the fold, which is consistent with our own estimate of $4.8 \mathrm{~km}$. In the same section, our Quaternary value of $0.7 \mathrm{~mm} / \mathrm{a}$ for the northern limb is similar to our Pleistocene rate of 0.6$0.8 \mathrm{~mm} / \mathrm{a}$ for the southern limb. The results derived from our model are therefore broadly consistent with other independent observations in both sections, suggesting that they are fairly robust at least for the most recent $(<5 \mathrm{Ma})$ history of folding.

These slip values can be added to the rates also recorded across the Yakeng anticline to better document the whole deformation accommodated across the southern Tianshan piedmont. In the Yaha section, the Yakeng anticline started growing at $\sim 5.5 \mathrm{Ma}$, at a slow rate of $0.16 \mathrm{~mm} / \mathrm{a}$ of slip until the Pleistocene. Both structures were therefore active at the same time and the total slip rate was $\sim 1.2-1.4 \mathrm{~mm} / \mathrm{a}$ from $\sim 4 \mathrm{Ma}$ until the Pleistocene. In the Kuche section, the long term slip rates across the Yakeng anticline are unknown, but, since the fold is neither tectonically nor 
topographically well developed, they are likely low or negligible $(<0.1 \mathrm{~mm} / \mathrm{a}$ ?). Thus, in this section, the deformation was mainly focused on only the Qiulitag fold. Consequently, over a long timescale ( $<3-5 \mathrm{Ma}$ ), a minimum of 0.8 to $1.4 \mathrm{~mm} / \mathrm{a}$ of slip was accommodated in the study region across these two structures. However, these values neglect the deformation that was likely accommodated across the northern and southern limbs of the Qiulitag fold in Kuche and Yaha, respectively. When compared to the Mio-Pliocene sediment progradation rates of $\sim 3.9 \mathrm{~mm} / \mathrm{a}$ measured across the same piedmont (Charreau et al., 2009), they suggest that a significant part of the total deformation was also accommodated across other inner structures during this period.

During the Pleistocene, the Yakeng anticline also experienced a strong increase in slip rate (Hubert-Ferrari et al., 2007). Indeed, $0.5 \mathrm{~mm} / \mathrm{a}$ and $\sim 1.5 \mathrm{~mm} / \mathrm{a}$ of additional slip was absorbed in the Yakeng anticline across the Kuche and the Yaha sections (Saint-Carlier et al., 2016), yielding total slip rates of $\sim 3 \mathrm{~mm} / \mathrm{a}$ in both sections. According to GPS measurements, $7-8 \mathrm{~mm} / \mathrm{a}$ of shortening is accommodated across the Tianshan range at the longitude of the Kuche section (e.g. Reigber et al., 2001). Therefore, this strong Pleistocene increase in slip rates suggests that a significant proportion (40-50\%) of the recent deformation of the whole Tianshan is now accommodated across the Qiulitage and Yakeng anticlines only and that the deformation has migrated from inner structures toward the external structures of the piedmonts. This acceleration, also observed in northern Tianshan, may suggest evolution of the orogen center toward a more steady topography (Charreau et al., 2018; Guerit et al., 2016).

\section{Acknowledgements}

E. Davy, A. Zitouni, R. Joussemet and the STEVAL crew (GeoRessources, Nancy) are acknowledged for technical support on the sample crushing and mineral separation. We also thank Jean-Philippe Avouac for his assistance during field work. The ASTER AMS national facility (CEREGE, Aix-en-Provence) is supported by the INSU/CNRS, the ANR through the "Projets thématiques d'excellence" program for the "Equipements d'excellence" ASTER-CEREGE action and IRD. All data are available in the main text, in the supplementary information or on request from the corresponding author. This is CRPG contribution $n^{\circ} 2726$.

\section{Data availability statement}

All data are available in the main text, in the supplementary information or on request from the corresponding author. 


\section{References}

Blard, P.-H., LUPKER, M., ROUSSEAU, M., 2019. MATLAB codes for computing paleoelevations or burial ages from paired-cosmogenic nuclides. MethodsX In press.

Charreau, J., Avouac, J.-P., Chen, Y., Dominguez, S., Gilder, S., 2008. Miocene to present kinematics of fault-bend folding across the Huerguosi anticline, northern Tianshan (China), derived from structural, seismic, and magnetostratigraphic data. Geology 36, 871-874. https://doi.org/10.1130/G25073A.1

Charreau, J., Gilder, S., Chen, Y., Dominguez, S., Avouac, J.-P., Sen, S., Jolivet, M., Li, Y., Wang, W., 2006. Magnetostratigraphy of the Yaha section, Tarim Basin (China): $11 \mathrm{Ma}$ acceleration in erosion and uplift of the Tian Shan mountains. Geology 34, 181. https://doi.org/10.1130/G22106.1

Charreau, J., Gumiaux, C., Avouac, J.-P., Augier, R., Chen, Y., Barrier, L., Gilder, S., Dominguez, S., Charles, N., Wang, Q., 2009. The Neogene Xiyu Formation, a diachronous prograding gravel wedge at front of the Tianshan: Climatic and tectonic implications. Earth Planet. Sci. Lett. 287, 298-310. https://doi.org/10.1016/j.eps1.2009.07.035

Charreau, J., Saint-Carlier, D., Dominguez, S., Lavé, J., Blard, P.-H., Avouac, J.-P., Jolivet, M., Chen, Y., ShengLi, W., Borwn, N.D., Malatesta, L.C., Rhodes, E., Team, A., 2017. Denudation outpaced by crustal thickening in the eastern Tianshan. Earth Planet. Sci. Lett. 479, 179-191.

Charreau, J., Saint-carlier, D., Lavé, J., Dominguez, S., Blard, P., Avouac, J., Brown, N.D., Claude, L., Shengli, W., Rhodes, E.J., 2018. Late Pleistocene acceleration of deformation across the northern Tianshan piedmont ( China ) evidenced from the morpho-tectonic evolution of the Dushanzi anticline. Tectonophysics 730, 132-140. https://doi.org/10.1016/j.tecto.2018.02.016

Dumitru, T. a, Zhou, D., Chang, E.Z., Graham, S. a, Hendrix, M.S., Sobel, E.R., Carroll, A.R., 2001. Uplift, exhumation, and deformation in the Chinese Tian Shan. Mem. - Geol. Soc. Am. 194, 71-99. https://doi.org/10.1130/0-8137-1194-0.71

Gosse, J.C., Phillips, F.M., 2001. Terrestrial in situ cosmogenic nuclides : theory and application. Quat. Sci. Rev. 20, 1475-1560.

Granger, D.E., Muzikar, P.F., 2001. Dating sediment burial with in situ-produced cosmogenic nuclides: theory, techniques, and limitations. Earth Planet. Sci. Lett. 188, 269-281. 
Guerit, L., Barrier, L., Jolivet, M., Fu, B., Métivier, F., 2016. Denudation intensity and control in the Chinese Tian Shan: new constraints from mass balance on catchment-alluvial fan systems. Earth Surf. Process. Landforms 41, 1088-1106. https://doi.org/10.1002/esp.3890

Hubert-Ferrari, A., Suppe, J., Gonzalez-Mieres, R., Wang, X., 2007. Mechanism of active folding of the landscape (southern Tianshan, China). J. Geophys. Res. 112, doi: 10.129/2006JB004362.

Reigber, C., Michel, G.W., Galas, R., Angermann, D., Klotz, J., Chen, J.Y., Papschev, A., Arslanov, R., Tzurkov Ishanov, M.C., V.E., 2001. New space geodetic constraints on the distribution of deformation in the Central Asia. Earth Planet. Sci. Lett. 191, 157-165.

Saint-Carlier, D., Charreau, J., Lavé, J., Blard, P.H., Dominguez, S., Avouac, J.P., Wang, S., Arnold, M., Aumaître, G., Keddadouche, K., Léanni, L., Chauvet, F., Bourlés, D.L., 2016. Major temporal variations in shortening rate absorbed along a large active fold of the southeastern Tianshan piedmont (China). Earth Planet. Sci. Lett. 434, 333-348. https://doi.org/10.1016/j.eps1.2015.11.041

Sun, J., Li, Y., Zhang, Z., Fu, B., 2009. Magnetostratigraphic data on Neogene growth folding in the foreland basin of the southern Tianshan Mountains. https://doi.org/10.1130/G30278A.1

Suppe, J., Sàbat, F., Anton Muñoz, J., Poblet, J., Roca, E., Vergés, J., 1997. Bed-by-bed fold growth by kink-band migration: Sant llorenç de Morunys, eastern Pyrenees. J. Struct. Geol. 19, 443-461. https://doi.org/10.1016/S0191-8141(96)00103-4

Thompson, S.C., Weldon, R.J., Rubin, C.M., Abdrakhmatov, K., Molnar, P., Berger, G.W., 2002. Late Quaternary slip rates across the central Tien Shan, Kyrgyzstan, central Asia 107. https://doi.org/10.1029/2001JB000596

Windley, B.F., Allen, M.B., Zhang, C., Zhao, Z.-Y., Wang, G.R., 1990. Paleozoic accretion and Cenozoic deformation of the Chinese Tien Shan Range, central Asia. Geology 18, 128-131.

Wu, C., Shen, J., Chen, J., Li, J., Xiang, Z., Xie, T., Song, Z., Wang, C., 2006. Preliminary study of late Quaternary crustal shortening rate along Kuqa depression in South Tianshan, Xinjiang. Seismol. Geol. 28, 279-288.

\section{Tables and figures caption}

Fig. 1: a. Topographic map of the Tianshan area showing the GPS velocity and location of the study area; b. satellite image of the study area showing the location of the Kuche section in the 
southern limb of the Qiulitag anticline; c. geological cross section of the Qiulitag fold along the Kuche river; d. geological cross section of the Qiulitag fold along the Yaha river..

Fig. 2: a. Satellite image of the Kuche river showing locations of the sampling sites for cosmogenic burial age determinations (KU1 to 8). The inset photo shows an example of a sampling site. Samples were mainly collected at the base of overhanging cliffs, inside caves, or inside deeply entrenched canyons to ensure negligible exposure to present-day cosmic rays. The samples were also collected at sites where there was $>20 \mathrm{~m}$ thickness of sediment above the sampling site in order to rule out possible muon penetration. The diagram on the right shows the stratigraphic ages derived from our cosmogenic burial dating and the magnetostratigraphic correlation of Sun et al. (2009) as a function of the depth along the Kuche section. The mean sediment accumulation rate and its uncertainty were constrained following the approach developed by York et al. (2004), using a general least-squares procedure that allows uncertainties in the stratigraphic thickness $(\sim 50 \mathrm{~m})$ as well as in the ages to be taken into account. The last three points of Sun's section were included in the calculation assuming an age uncertainty of $10 \mathrm{ka}$; b. satellite image of the Yaha river showing the location of the cosmogenic depth profile (gray star). A Trimble DGPS topographic device was used to acquire high resolution topographic measurements of the marker (red circles) and of the river bed (yellow circles). The inset is a Google Earth image capture of the terrace showing the location of the cosmogenic depth profile (gray star). The two elevation profiles are shown on the right. We determined the vertical offset and its uncertainty by estimating the slopes and intercepts and associated uncertainties of the best-fit lines representing the surface on both side of the axial surface (Thompson et al., 2002). The vertical offset measured across this profile is interpreted as a fold scarp and is converted into a horizontal component of slip using the bedding dip change that can be measured along the river and on the seismic line (Figs. 2, $\mathrm{C}$ and 12 of Hubert-Ferrari et al. (2007)). The sampling points for the cosmogenic depth profile are shown in the bottom photograph along with the measured concentrations and the results of the best-fit model (red curve) (see Saint-Carlier et al. (2016) and the Supplementary Information for further details of the inversion procedure). $t_{\exp }$ and $C_{\text {inh }}$ are the inverted exposure age and the inherited concentration, respectively. 
Fig. 3: a. Growth strata (red lines) predicted by our model using the surface bedding dip adjustment method and comparison with the seismic line drawing (black lines); b. Measured (gray dots) and modeled (red circles) dip angles plotted against horizontal distance along the section. The black line indicates the expected dip if only pre-growth strata are considered; c. temporal evolution of slip rates across the Qiulitag anticline at the Yaha section for each of the modeled layers. Assuming $5^{\circ}$ for the $1 \sigma$ uncertainty in each individual dip angle measurement, we used the Chi-square criterion to estimate the resulting uncertainty in shortening at the $67 \%$ $(1 \sigma)$ confidence level. This uncertainty accounts for measurement errors and for the natural roughness of bedding surfaces. Each age is assigned to a confidence interval corresponding to the chron defined by the magnetostratigraphic datapoints that bracket the stratigraphic location of the point of interest. However, for each point we assumed a symmetrical uncertainty using the maximum limit. Following the approach developed by York et al. (2004), the average shortening rate and its uncertainty were constrained using a general least-squares procedure that allows the uncertainties in the shortening estimates as well as in the ages to be taken into account

Fig. 4: same as Figure 3 but for the Kuche section. The red line in Figure $4 \mathrm{~b}$ corresponds to the smoothed dip angles.

Table 1: a. Cosmogenic ${ }^{10} \mathrm{Be}$ and ${ }^{26} \mathrm{Al}$ results for burial samples. 'Ba' are burial ages assuming no previous sediment storage and an initial ${ }^{26} \mathrm{Al} /{ }^{10} \mathrm{Be}$ ratio of 6.5 . 'Bac' are burial ages calculated using the ${ }^{26} \mathrm{Al} /{ }^{10} \mathrm{Be}$ ratio measured in the present-day river sand. Cosmogenic results for burial samples collected in the Kuche section; b. Cosmogenic results of the depth profile samples. 
Table 1a: Cosmogenic ${ }^{10} \mathrm{Be}$ and ${ }^{26} \mathrm{Al}$ results of burial-age samples. 'Ba' are burial ages calculated assuming no previous sediment storage and an initial ${ }^{26} \mathrm{Al} /{ }^{10} \mathrm{Be}$ ration of 6.5 . ' $\mathrm{Ba}_{\mathrm{c}}$ ' are burial ages calculated using the ${ }^{26} \mathrm{Al} /{ }^{10} \mathrm{Be}$ ratio measured in the present river sand.

\begin{tabular}{|c|c|c|c|c|c|c|c|c|c|}
\hline \multirow{2}{*}{ Sample } & \multicolumn{2}{|c|}{ Coordinates $\left(^{\circ}\right)$} & \multirow{2}{*}{$\begin{array}{c}\text { Mass of quartz } \\
\text { (g) }\end{array}$} & \multirow{2}{*}{$\begin{array}{c}\text { Number of } \\
\text { clasts }\end{array}$} & \multicolumn{2}{|c|}{ Concentration $\left(10^{4}\right.$ at. $\mathrm{g}^{-}$} & \multirow{2}{*}{${ }^{10} \mathrm{Be} /{ }^{26} \mathrm{Al}$} & \multicolumn{2}{|c|}{ Burial ages $(\mathrm{Ma})$} \\
\hline & Lat. & Lon. & & & ${ }^{10} \mathrm{Be}$ & ${ }^{26} \mathrm{Al}$ & & $\mathrm{Ba}$ & $\mathrm{Ba}_{\mathrm{c}}$ \\
\hline River sand & 41.8744 & 83.0603 & 15.57 & Sand & $6.9 \pm 0.3$ & $25.3 \pm 3.1$ & $3.7 \pm 0.5$ & $1.3 \pm 0.3$ & n.a \\
\hline TS12-KU-01 & 41.7964 & 83.3226 & 10.612 & 30 & $1.3 \pm 0.2$ & $0.7 \pm 0.7$ & $0.5 \pm 0.5$ & $5.4 \pm 2$ & $4.1 \pm 2.3$ \\
\hline TS12-KU-02 & 41.8775 & 83.6252 & 34.17 & 28 & $3.4 \pm 0.6$ & $3.1 \pm 2.1$ & $0.9 \pm 0.6$ & $4.5 \pm 1.7$ & $3.2 \pm 2$ \\
\hline TS12-KU-03 & 41.8750 & 83.8750 & 75.23 & 28 & $3.3 \pm 1.2$ & $2.1 \pm 1.7$ & $0.6 \pm 0.5$ & $5.1 \pm 2.1$ & $3.8 \pm 2.4$ \\
\hline TS12-KU-04 & 41.8725 & 83.1431 & 57.03364 & 28 & $2.3 \pm 0.3$ & $3.1 \pm 2.4$ & $1.4 \pm 1.7$ & $3.6 \pm 1.8$ & $2.3 \pm 2.1$ \\
\hline TS12-KU-05 & 41.8708 & 83.0581 & 38.33 & 20 & $3.9 \pm 0.3$ & $5.8 \pm 3$ & $1.5 \pm 1.9$ & $3.4 \pm 1.4$ & $2.1 \pm 1.7$ \\
\hline TS12-KU-06 & 41.8694 & 83.0573 & 25.99 & 26 & $2.8 \pm 0.4$ & $6.4 \pm 2.1$ & $2.3 \pm 2$ & $2.4 \pm 0.9$ & $1.1 \pm 1.2$ \\
\hline TS12-KU-07 & 41.8656 & 83.0571 & 10.2769 & 25 & $2.3 \pm 0.2$ & $3 \pm 1.6$ & $1.3 \pm 0.7$ & $3.8 \pm 1.6$ & $2.5 \pm 1.9$ \\
\hline TS12-KU-08 & 41.8656 & 83.0571 & 26.26 & 26 & $1.9 \pm 0.4$ & $5.5 \pm 2.1$ & $2.9 \pm 1.7$ & $1.9 \pm 1.1$ & $0.6 \pm 1.4$ \\
\hline
\end{tabular}

Table 1b: Cosmogenic results of the depth profile samples

\begin{tabular}{lcccc}
\hline Sample name & $\begin{array}{c}\text { Depth } \\
(\mathrm{cm})\end{array}$ & $\begin{array}{c}\text { Sampling } \\
\text { thickness } \\
(\mathrm{cm})\end{array}$ & Sample type & $\begin{array}{c}\text { Mass of } \\
\text { quartz (g) }\end{array}$ \\
\hline
\end{tabular}

This article is protected by copyright. All rights reserved 


\begin{tabular}{lccccc} 
TS12_YA_T1_P0a & 0 & 5 & 1 cobble & 10 & $67.3 \pm 2.3$ \\
TS12_YA_T1_P0b & 0 & 5 & 7 cobbles & 10.67 & $74.6 \pm 2.4$ \\
TS12_YA_T1_P0c & 0 & 5 & 35 coarse pebbles and cobbles & 9.83 & $71.5 \pm 2.2$ \\
\cline { 3 - 5 } & & & & mean: & $71.1 \pm 3.7$ \\
TS12_YA_T1_P1 & -19.5 & 2.5 & sand and fine pebbles & 10.69 & $56.7 \pm 2$ \\
TS12_YA_T1_P2 & -46 & 4 & sand and fine pebbles & 13.01 & $47.1 \pm 1.5$ \\
TS12_YA_T1_P3 & -120 & 5 & sand and fine pebbles & 3.73 & $22.4 \pm 1.4$ \\
TS12_YA_T1_P4 & -210 & 5 & sand and fine pebbles & 18.57 & $12.9 \pm 0.5$ \\
TS12_YA_T1_P5 & -400 & 20 & sand and fine pebbles & 14.27 & $9 \pm 0.5$ \\
\hline
\end{tabular}

This article is protected by copyright. All rights reserved 


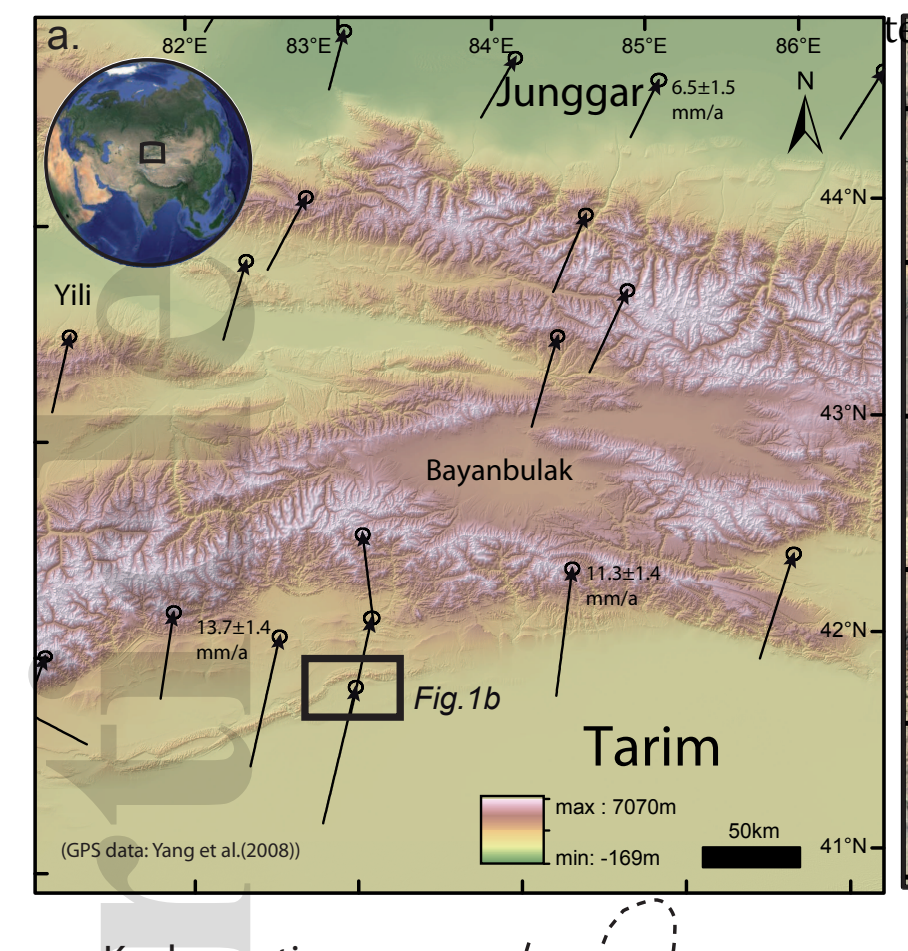

C. Kuche section

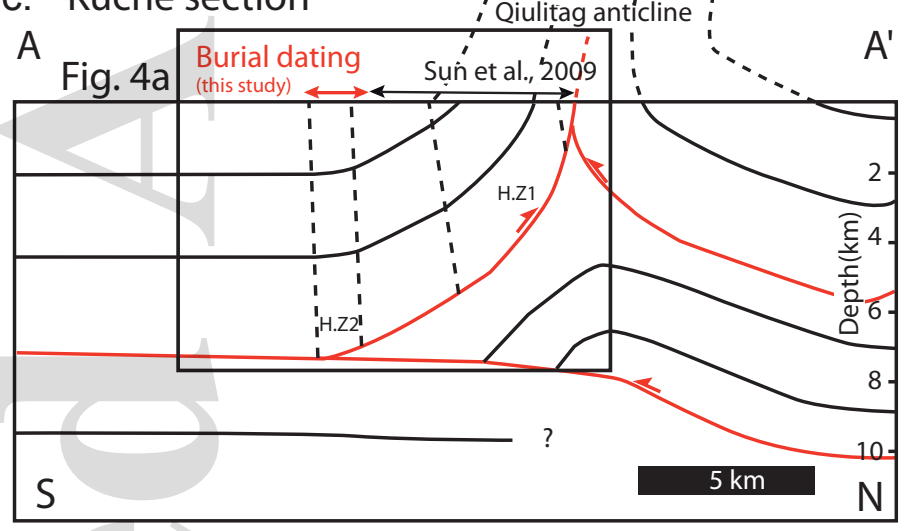

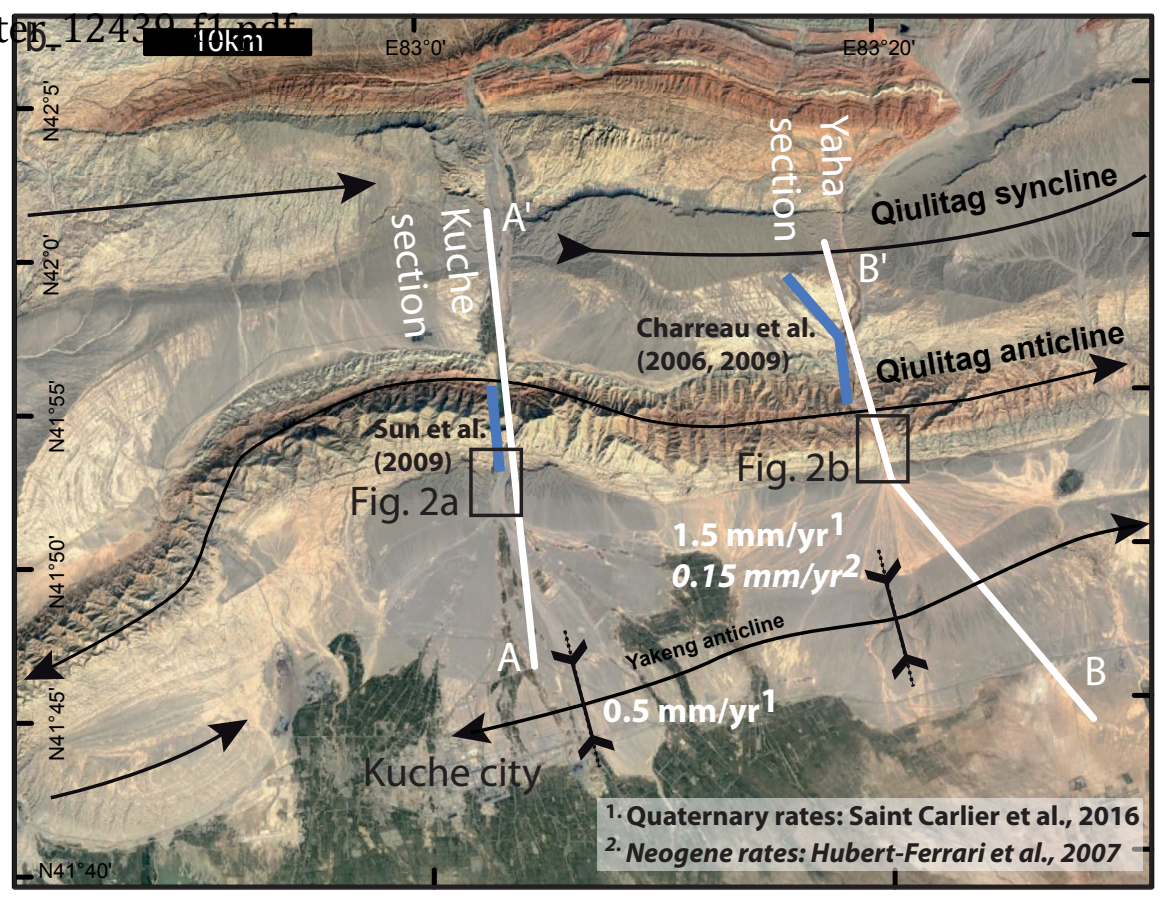

d. Yaha section

Fig. 3a
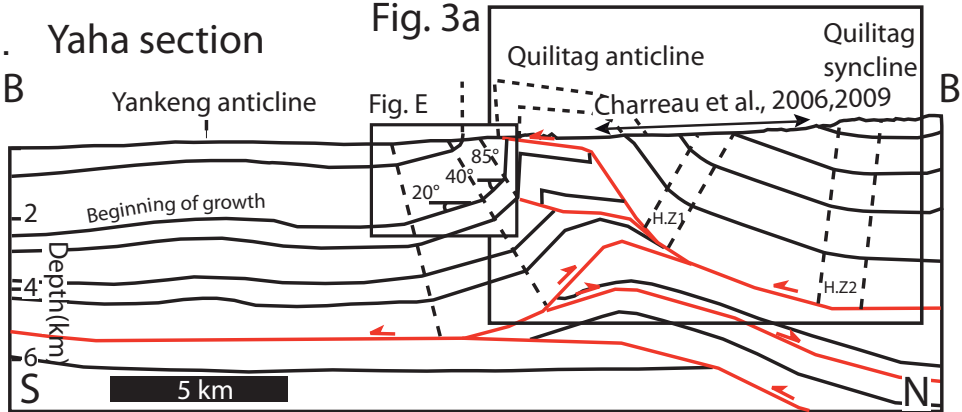

- - - Axial surfaces

H.Z: Hinge zone

Fig. 1

This article is protected by copyright. All rights reserved 
a.

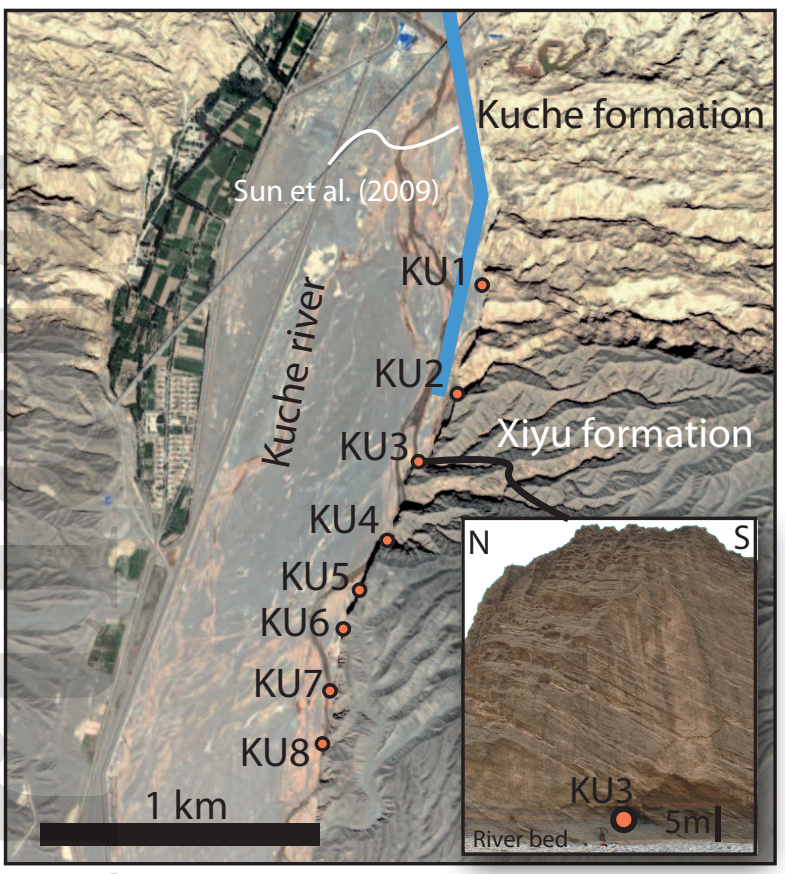

b.

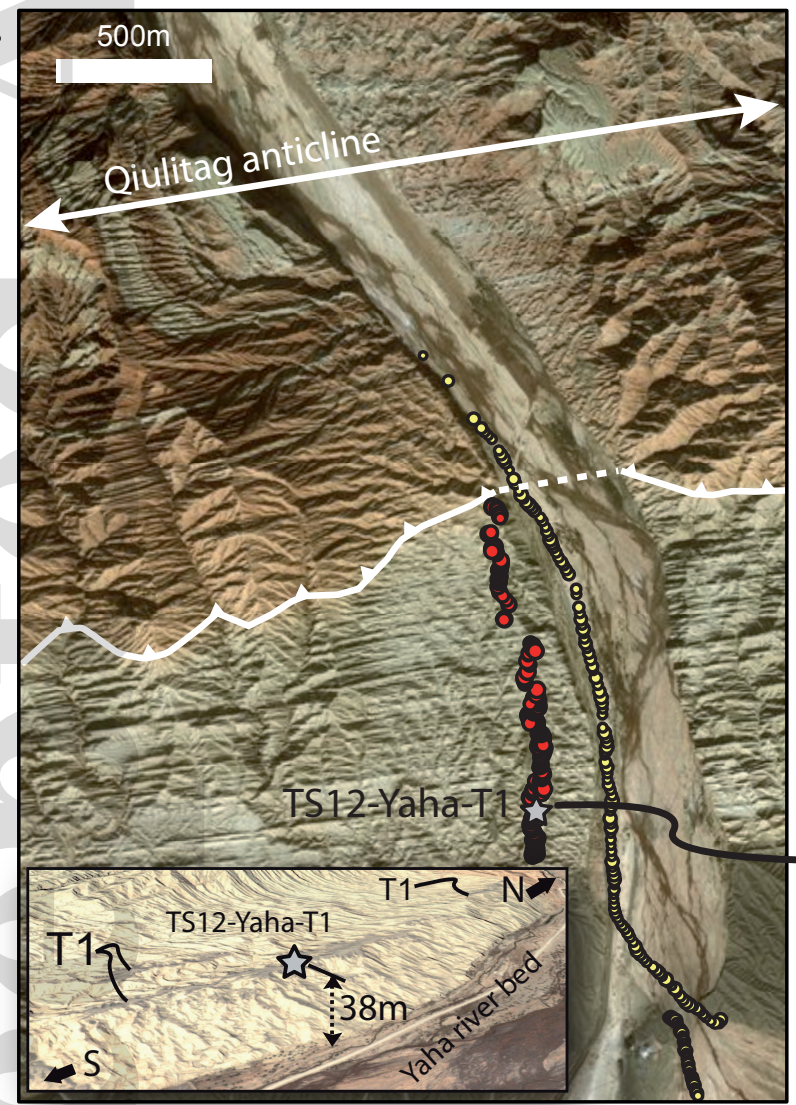

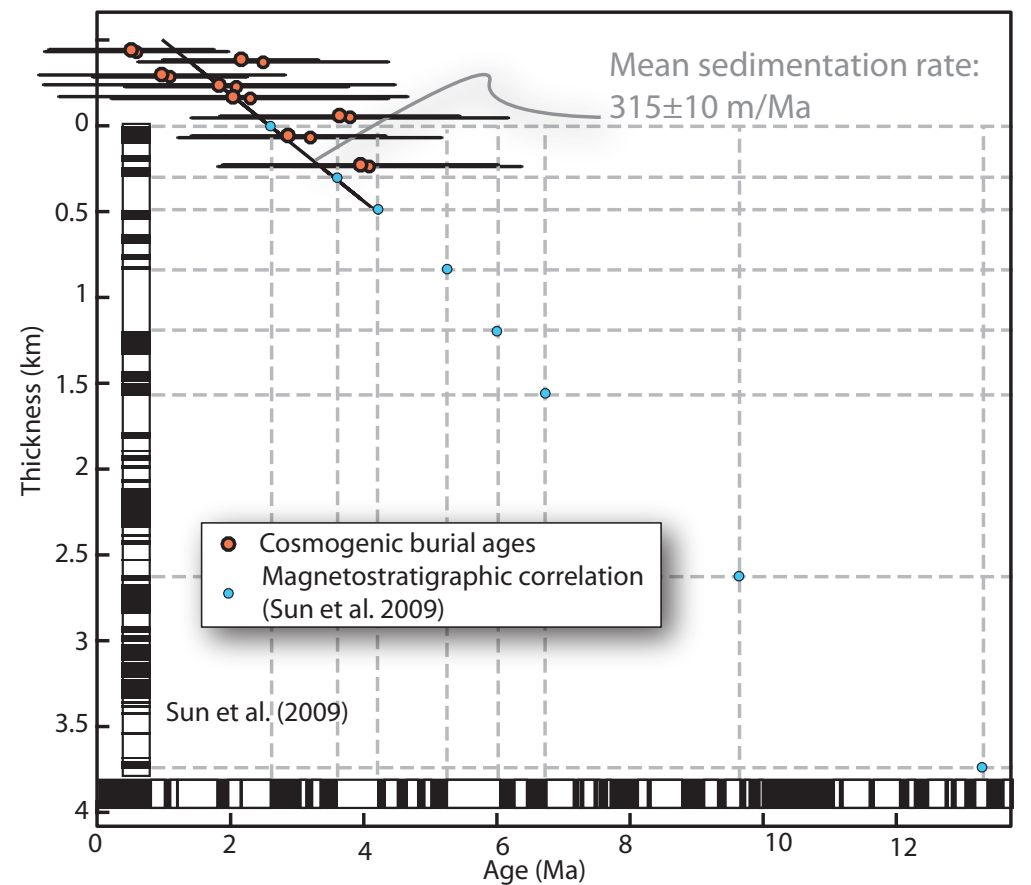
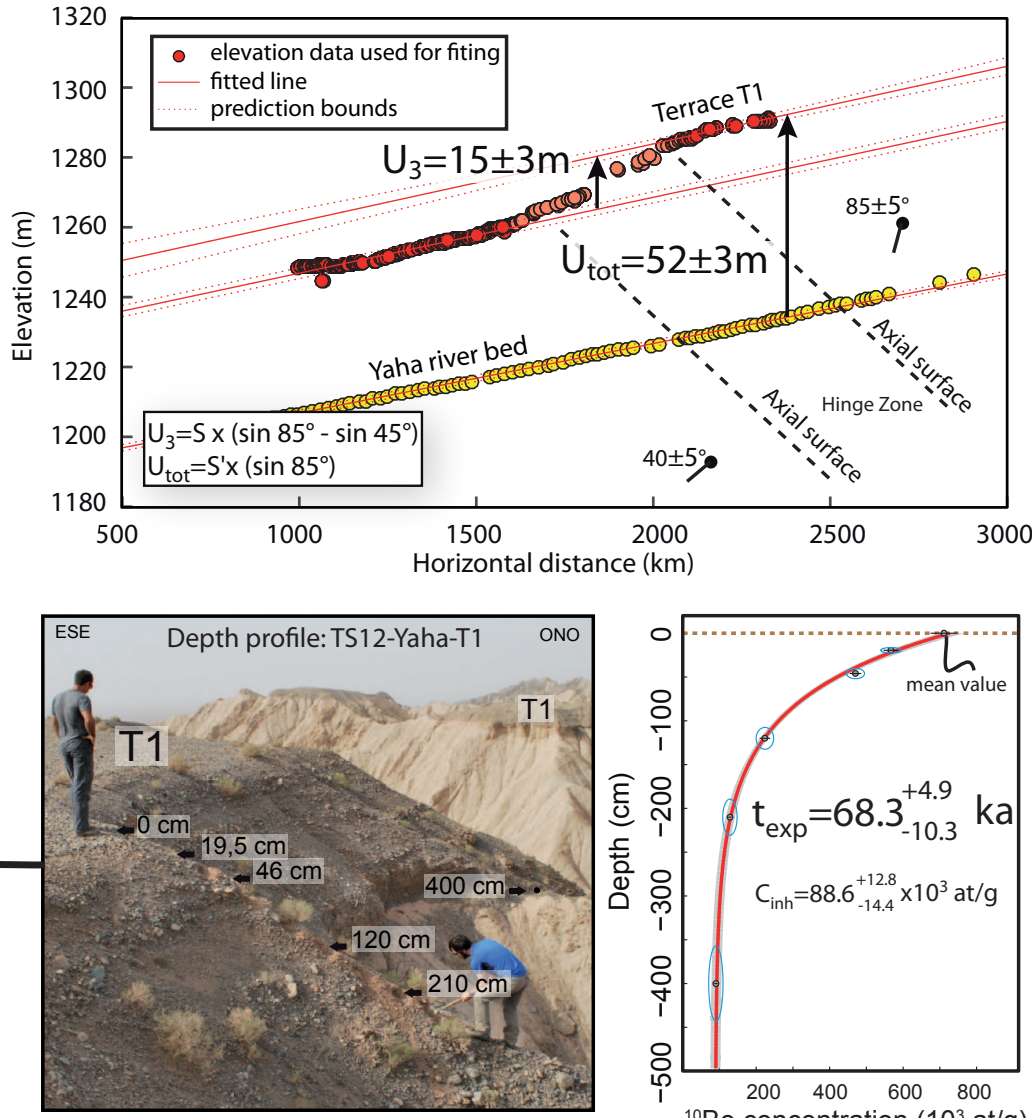

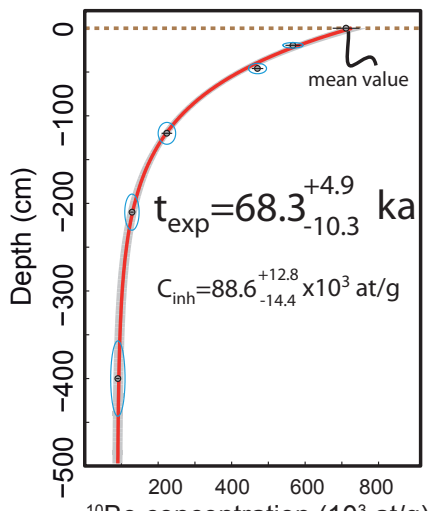

${ }^{10} \mathrm{Be}$ concentration $\left(10^{3} \mathrm{at} / \mathrm{g}\right)$

This article is protected by copyright. All rights reserved 

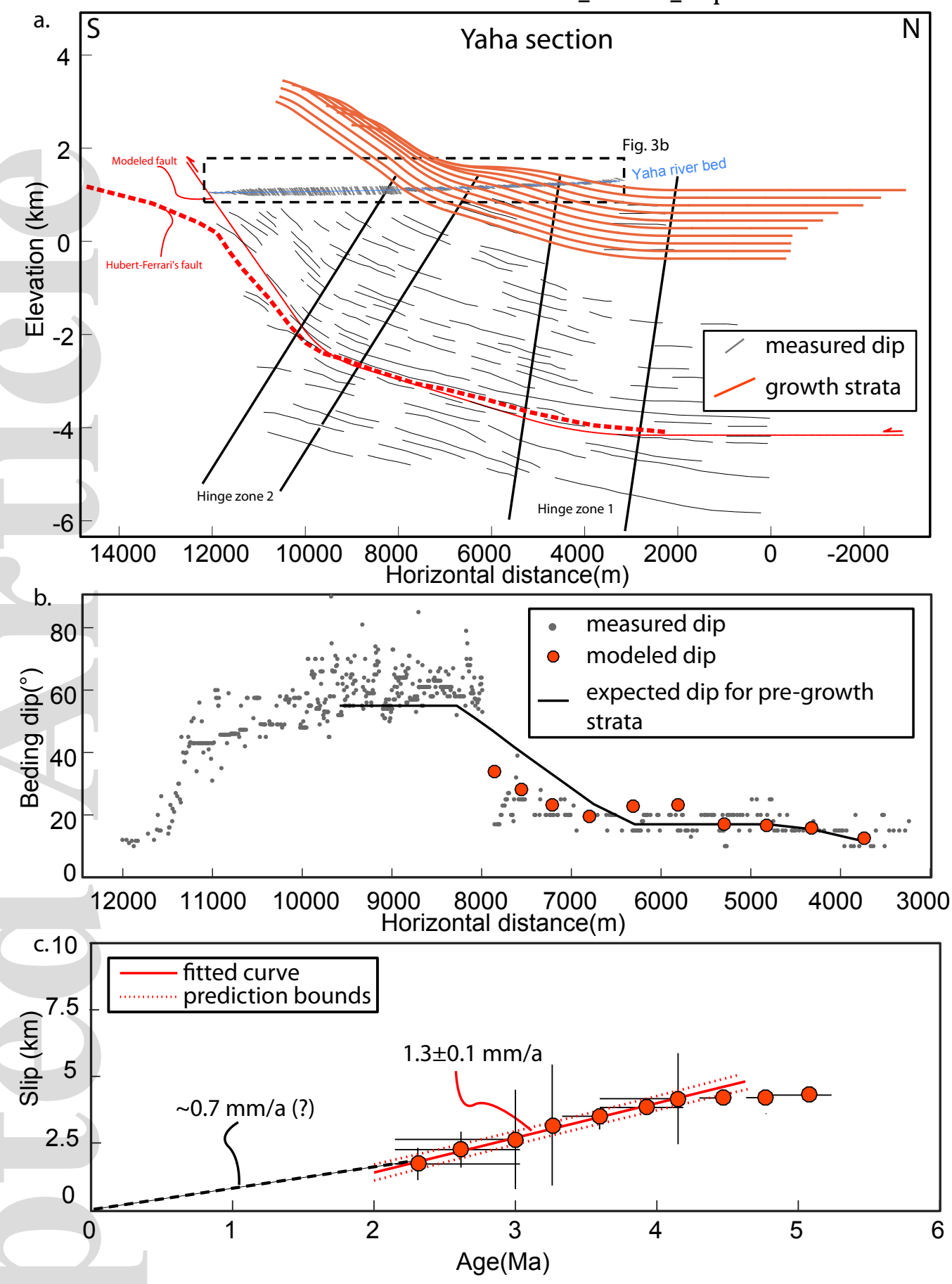

\section{Fig. 3}



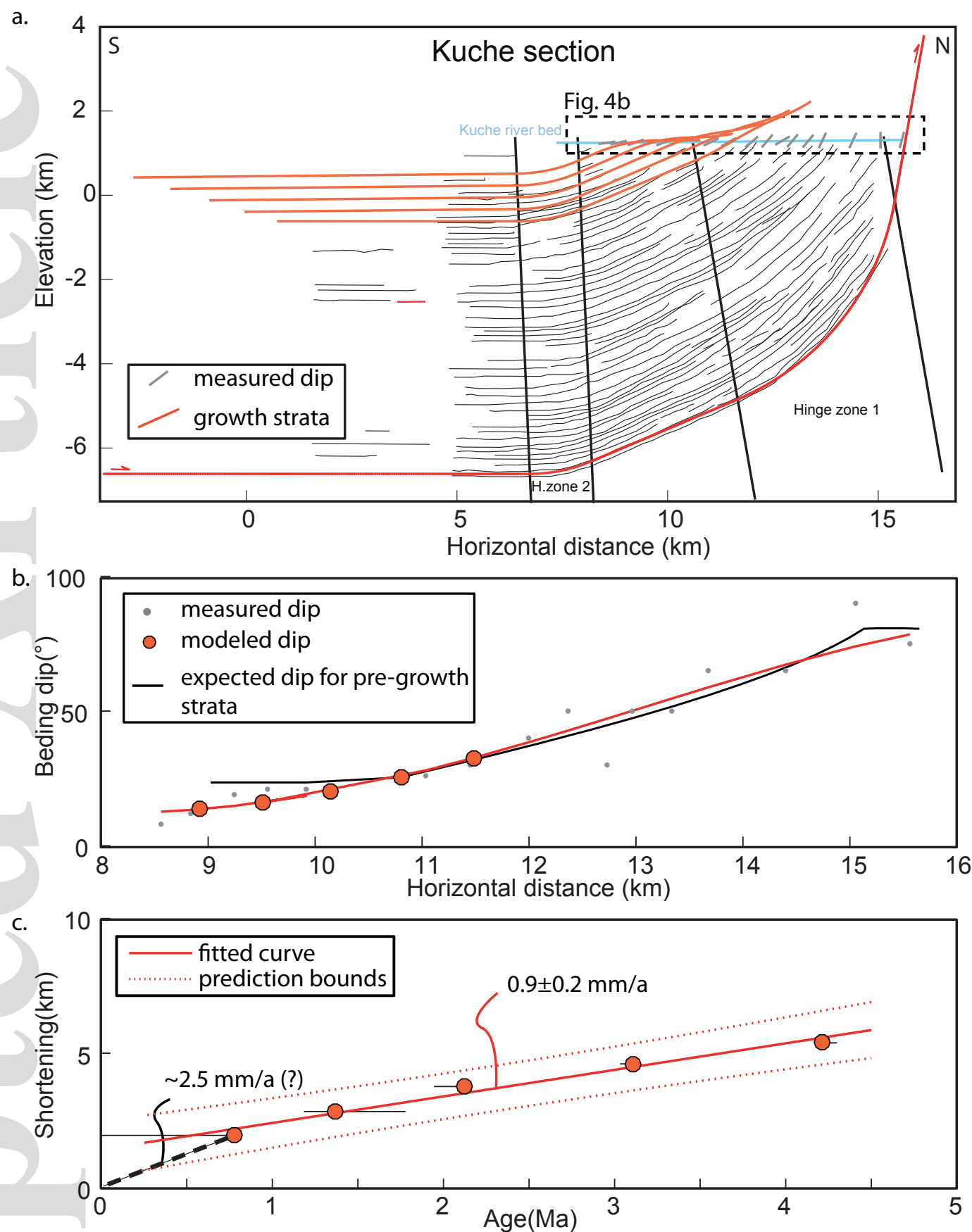

Fig. 4 